\title{
Rethinking Development Strategy -The Importance of the Rural Non Farm Economy in Growth and Poverty Reduction in Pakistan
}

\author{
Sohail Jehangir Malik
}

\begin{abstract}
The structural transformation of Pakistan's economy has not been accompanied by a concomitant decline in the proportion of labor employed in agriculture. While this transformation has resulted in a non-farm sector that is large and growing it has not lead to the rapid absorption of the pool of relatively low productivity labor away from the agriculture sector, as predicted by conventional development theory embodied in the models of the 1960s. Despite the obvious importance of the role of a vibrant rural non-farm economy (RNFE), and in particular, a vibrant non-farm services sector to address the challenges of poverty, food security, agricultural growth and rural development, this sector has received inadequate attention in the debate in Pakistan. Based on a review of literature and data from two large surveys - the Rural Investment Climate Survey of Pakistan 2005 and the Surveys of Domestic Commerce 2007 - this paper attempts to analyze the factors underlying the low level of development of the rural non farm economy and the potential role it can play in Pakistan's economic development.
\end{abstract}

JEL Classification: R11, R23

Keywords: Pakistan, Poverty, Rura1, Development

\section{Background}

The development community is increasingly coming to realize the potential contribution of the rural non-farm sector to economic growth, directly because of its size and its responsiveness to growing agricultural, urban, and export markets, and indirectly through provision of financing, processing, marketing and other support services that stimulate and accelerate agricultural growth.

* Chairman, Innovative Development Strategies (Pvt) Ltd. All the usual disclaimers apply. 
Functionally, the rural ${ }^{1}$ non-farm economy (RNFE) is supposed to play a pivotal role in the process of structural transformation, during which the agricultural share of total national output declines and transfers of capital and labor drive a corresponding rise in manufacturing and services.

One major realization, however, which has led to the recent focus on trying to understand the dynamics of the RNFEs, has been a consistent pattern in developing countries; the share of the agriculture sector has declined where the share of the labor associated with agriculture has not declined at the same pace.

\section{Figure 1: Share of Major Sectors in GDP and in Total Labour Employed 2005-06}

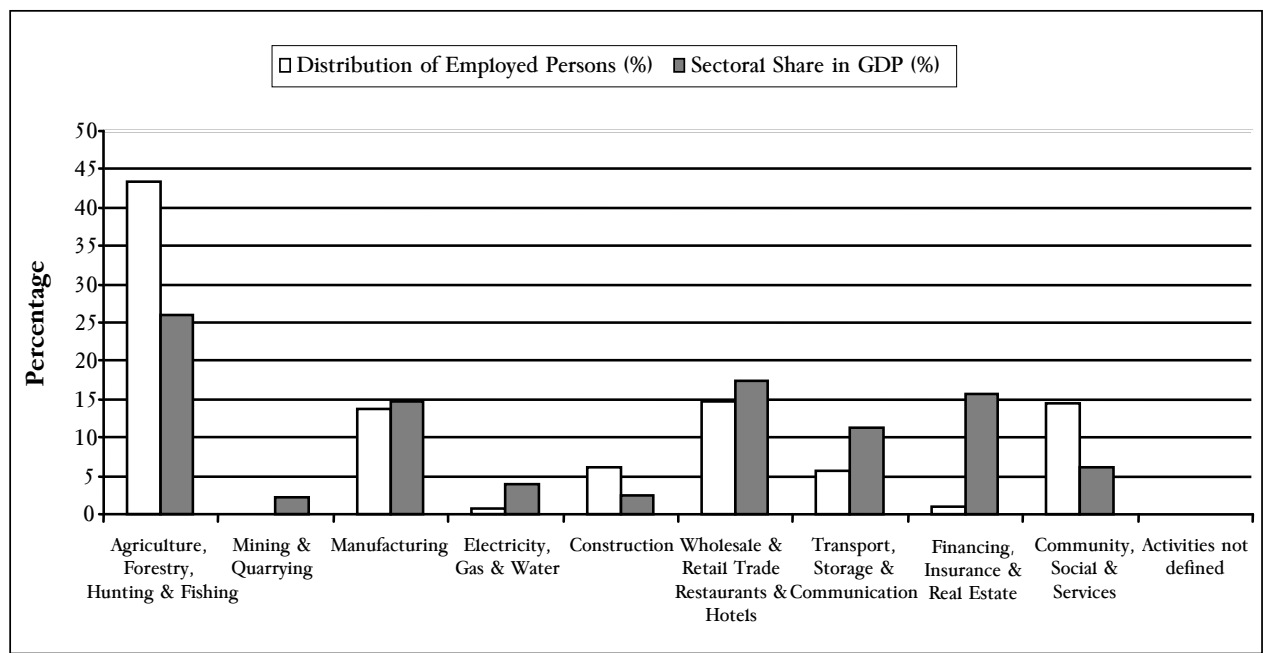

This is quite evident from the data for Pakistan based on the Pakistan Economic Survey and the Labour Force Survey for the year 200506 presented in Figure-1 above.

"Because many of the resources flow from agriculture to the secondary and tertiary sectors of the economy transit functionally and spatially via the RNFE, an understanding of the forces that drive change in the RNFE becomes central to understanding the processes that drive overall economic growth and poverty reduction". This understanding has sadly been missing in the debate on development economics in Pakistan.

1 The Local Government Ordinance of 2001 has obliterated the distinction between rural and urban in Pakistan. However, the debate still holds given the spatial and other characteristics underlying the potential of, as well as the constraints to development that arise from consideration of these activities. 
Conventional development economics associated rural economies primarily with agriculture. This was due in large part to the predominance of agriculture in rural life. However, evidence based on household level socio-economic surveys conducted during the 1980s established the, often heavy, reliance of rural economies on activities other than farming. The development community was barely coming to a fuller understanding of the rural non-farm economies when the process of globalization starting from the 1990s brought in increasing complexities in the form of new opportunities for rural goods and services through expanding domestic urban markets and the opening up of new markets abroad. The enormous increase in the availability of information and communication technology greatly facilitated this potential boon. However, with the new opportunities have also come new challenges.

"Liberalization, by reducing direct government involvement in production and marketing, has opened up new market opportunities for the private sector, particularly in agricultural processing, input supply, and trade. Relaxed controls on foreign exchange and foreign investment have unleashed a flood of foreign direct investment into Latin America, Asia, and Africa. As a result, large exporters, agribusiness firms, and supermarket chains increasingly penetrate rural economies of the developing world, altering the scale and structure of rural supply chains as they do. These new investments open up opportunities for some rural suppliers to access new markets. But they expose others to new threats by opening up the RNFE to competition from cheap manufactured imports and by imposing quantity requirements and quality standards that risk excluding undercapitalized rural enterprises on which the rural poor often depend" [Haggblade et al (2007)].

In fact the predominant growth-centric development paradigm of the past decade or so in Pakistan completely ignored the crucial role of the RNFE as is obvious from the peripheral emphasis given to agriculture and the rural sector in government policy. The aspirations for future economic development of the country reflected in the slogans of the government to reap the "gains from globalization" and the dividends from the "demographic boon" were not based on any deep understanding of the structure, dynamics, potential and constraints of the rural non-farm economy without which the so-called demographic boon has all the potential of turning into a demographic death trap and the gains from globalization into a sorry snuffing out of any potential for growth and development by those global partners who are more competitive than us. 
This paper, therefore, is divided into four sections. Following this introductory section the available international evidence on the potential of the rural non-farm economy for growth and poverty reduction is presented in the second section. The third section presents similar evidence from Pakistan while the fourth section draws together the obvious implications.

\section{The International Evidence ${ }^{2}$}

The available international evidence suggests that the rural non-farm economies are generally large.

Table-1:Non-Farm Share of Rural Income (\%)

\begin{tabular}{lc}
\hline Country & Share \\
\hline Africa & $42 \%$ \\
Asia & $32 \%$ \\
Latin America & $40 \%$ \\
\hline
\end{tabular}

The available evidence also suggests that they are growing rapidly.

Table-2: Growth in Non-Farm Share of Farm Incomes

\begin{tabular}{ccccc}
\hline China & \multicolumn{2}{c}{$\begin{array}{c}\text { Rural Non-Farm } \\
\text { Share of }\end{array}$} & India & $\begin{array}{c}\text { Non-Farm Share of } \\
\text { Rural Income }\end{array}$ \\
\hline & $\begin{array}{c}\text { Farm hh } \\
\text { Income }\end{array}$ & $\begin{array}{c}\text { National } \\
\text { Income }\end{array}$ & & \\
1980 & $17 \%$ & $4 \%$ & 1968 & $26 \%$ \\
1985 & $25 \%$ & $7 \%$ & 1980 & $36 \%$ \\
1990 & $26 \%$ & $10 \%$ & 2000 & $46 \%$ \\
1997 & $39 \%$ & $28 \%$ & & \\
& & & Taiwan & Non-Farm Share of Farm \\
& & & 1970 & hh Income \\
& & & 1975 & $45 \%$ \\
& & & 1980 & $47 \%$ \\
& & & & $65 \%$ \\
\hline
\end{tabular}

${ }^{2}$ Data in this section are based on Steven Haggblade, Peter B. R. Hazell, and Thomas Reardon, 2007. 
The evidence also suggests that there is great heterogeneity in the RNFEs that is reflected in a comparison of rural non-farm employment shares. This heterogeneity exists across activities and location.

Table-3: Heterogeneous Activities

\begin{tabular}{lcccc}
\hline \multicolumn{4}{c}{ Rural Non-Farm Employment Shares } \\
\hline \multirow{4}{*}{ Africa } & Manufacturing & Trade & Services & Construction Etc \\
Asia & $23 \%$ & $22 \%$ & $25 \%$ & $30 \%$ \\
Latin America & $28 \%$ & $26 \%$ & $32 \%$ & $14 \%$ \\
\hline
\end{tabular}

Services and commerce together generally account for the bulk of rural non-farm activity, although shares vary perceptibly among countries and across rural regions. Rural manufacturing, despite the considerable attention it has received, normally accounts for only about 20 to 28 percent of total rural non-farm employment in developing countries.

There is also a great heterogeneity of wage rates across activities. Evidence from a survey in Sudan presented below highlights this.

Table-4: Heterogeneous Wage Rates - Sudan

\begin{tabular}{lcc}
\hline Sudan & $\begin{array}{c}\text { Income Per Day } \\
\text { (Pounds) }\end{array}$ & Sector \\
\hline Carpet Making & 21 & Manufacturing \\
Pot Making & 23 & Manufacturing \\
Water Selling & 75 & Commerce \\
Food Selling & 80 & Commerce \\
Blacksmithing & 150 & Services \\
Construction & 180 & Services \\
\hline
\end{tabular}

The heterogeneity of wages is also the result of varying capital intensities associated with these enterprises which lead to varying returns to labor. 
Table-5: Heterogeneity in Capital Intensities and Returns to Labor Bangladesh

\begin{tabular}{lccc}
\hline Activity & K/Worker (Tk) & VA/Worker (Tk/day) & Female Workers \\
\hline Tailoring & 5,000 & 28 & $20 \%$ \\
Carpentry & 3,010 & 20 & $4 \%$ \\
Handloom & 1,600 & 15 & $38 \%$ \\
Pottery & 800 & 12 & $47 \%$ \\
Paddy husking & 300 & 7 & $56 \%$ \\
Bamboo products & 310 & 5 & $49 \%$ \\
Coir rope & 145 & 4 & $64 \%$ \\
\hline
\end{tabular}

This inherent heterogeneity highlights quite conclusively the need for more disaggregated and detailed analyses of the RNFE and a move away from the one size fits all approach to policy making. For Pakistan, it highlights the need for more scientific research based policymaking. This is especially so since the equity impact of the rural non-farm economy varies since the poor dominate certain segments and the rich dominate others. Available estimates indicate that non-farm incomes are equity enhancing in some countries, neutral in others and inequitable in still others.

Table-6: The Estimated Equity Impact of Non-Farm Incomes

\begin{tabular}{lcccccc}
\hline \multicolumn{5}{c}{ Rural Non-Farm Income as Share of Total } \\
\hline & Equity Enhancing & \multicolumn{2}{c}{ Neutral } & \multicolumn{2}{c}{ Inequitable } \\
\hline & Kenya & Pakistan & India & Ethiopia & Ecuador & Vietnam \\
Poorest & 82 & 75 & 32 & 32 & 22 & 40 \\
Middle & 45 & 36 & 38 & 30 & 37 & 50 \\
Richest & 40 & 21 & 31 & 31 & 64 & 82 \\
\hline
\end{tabular}

The evidence reported in the table above indicates that non-farm incomes in Pakistan are currently equity enhancing.

Obviously the equity impact depends upon the linkages of the rural non-farm economy and the employment potential in each. The growth linkages of the rural non-farm economy run in both directions. These include: 
- Production linkages

- Consumption linkages

- Labor market linkages

- Investment linkages

- Spatial linkages

The rapid growth of supermarkets, a recent phenomenon, highlights the growing importance of the consumption linkages. This is reflected in the growing shares of supermarkets in food retailing.

Table-7: Supermarkets Share in Food Retailing

\begin{tabular}{lcc}
\hline Country & 1990s & 2000s \\
\hline Latin America & $20 \%$ & $60 \%$ \\
China & $30 \%$ & $48 \%$ \\
Kenya & $6 \%$ & $21 \%$ \\
\hline
\end{tabular}

The international debate is now concentrating on the impact of growth linkages. Obviously a holistic approach to the overall analysis is required. Only a careful analysis based on sound empiricism of each linkage and its interaction with the others can enable identification of the potential constraints and the definition of policies that can ensure maximal overall growth and poverty reduction impacts. The need for sound empirical research is great.

The available international literature is also now increasingly concentrating on the other "motors" of non-farm growth such as:

- Technology

- Export markets

- Foreign investment; and

- Globalization

These are the emerging areas for research on RNFEs.

This short review of available international evidence on the role of rural non-farm economies in pro-poor growth confirms that a large number of the poor depend on the RNFEs, but that RNFE growth does not automatically 
benefit the poor. Also, it is not a reliable engine of growth, but requires considerable research and policy support to make it so. Given the large inherent heterogeneity in the sector, policy research needs to provide "situation-specific diagnostics" to facilitate maximal participation by the poor.

\section{Evidence from Pakistan}

The importance of the rural non-farm economy for Pakistan cannot be over-emphasized. Pakistan's economy is largely rural and so is its poverty; more importantly over half of the rural poor are non-farm households. In Pakistan, poverty is higher in the non-farm households than it is in farm households. Hence there is a great need for a diversified and vibrant nonfarm sector for rural poverty reduction. Such a sector can mop up the excess low productivity labor that characterizes Pakistan's agriculture, in addition to providing a fillip to agricultural diversification and value-addition. This is not the case presently. More than half of the rural poor in Pakistan are in the non-farm sector.

Figure-2: Pakistan's Rural Poor 2004-05: More than Half are in the NonFarm Sector

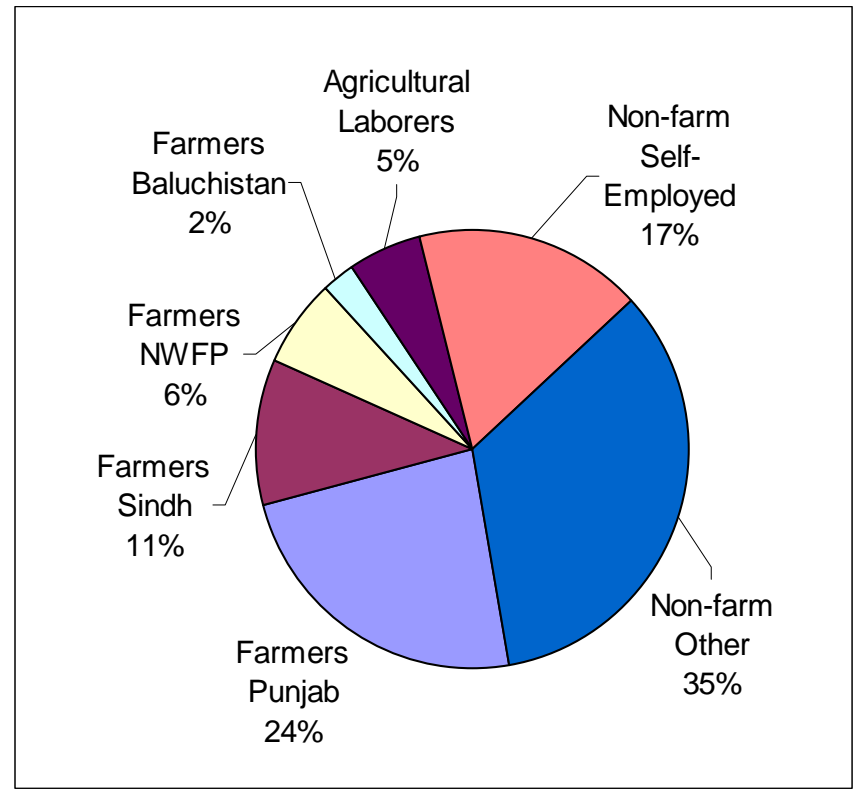

Source: Calculated from PSLM 2004-05 data

Notes: The poor are defined as households in the bottom 40 percent of the rural adult equivalent per capita expenditure distribution. Livestock herders who do not receive any crop income, ( 4 percent of the rural poor), are included in the other non-farm category. 
The data from the Agriculture Census of Pakistan 2000 shows that even farm households draw a significant share of their incomes from nonfarm sources. This underscores the need for a better understanding of Pakistan's non-farm economy.

Table-8: Sources of Non-farm Income by Type of Household

\begin{tabular}{lccc}
\hline $\begin{array}{c}\text { Source of Non-Farm } \\
\text { Income }\end{array}$ & $\begin{array}{c}\text { Farm } \\
\text { Households }\end{array}$ & $\begin{array}{c}\text { Non-Farm } \\
\text { Households }\end{array}$ & $\begin{array}{c}\text { Livestock } \\
\text { Holders }\end{array}$ \\
\hline Service & 11.9 & 22.7 & 8.0 \\
Business & 7.1 & 19.5 & 8.4 \\
Livestock & 3.0 & 0.3 & 9.4 \\
Remittances & 2.9 & 1.7 & 1.3 \\
Agriculture Labor & 21.6 & 4.9 & 14.9 \\
Non-Agri. Labor & 18.5 & 42.5 & 46.8 \\
Rent & 1.6 & 0.7 & 0.9 \\
Poultry & 0.2 & 0.2 & 0.4 \\
Others & 6.6 & 7.5 & 9.9 \\
None & 26.5 & 0.0 & 0.0 \\
\hline
\end{tabular}

Two recent large-scale surveys provide interesting insights into the structure of the rural non-farm economy in Pakistan. These are the Rural Investment Climate Survey (RICS) $2005^{3}$ and the Surveys of Domestic Commerce $2006^{4}$. The Rural Investment Climate Survey shows that rural enterprises are predominantly related to trade and services.

\footnotetext{
${ }^{3}$ The survey covered 2000 enterprises (Production, Trade and Services) and 1500 households in Punjab, Sindh and NWFP.

${ }^{4}$ The survey covered 2000 enterprises (Retail, Wholesale, Storage, Transport and Real Estate) in the four Provinces of Pakistan.
} 
Figure-3: Distribution of Enterprises by Type for Rural and Small Towns in Punjab, 2005

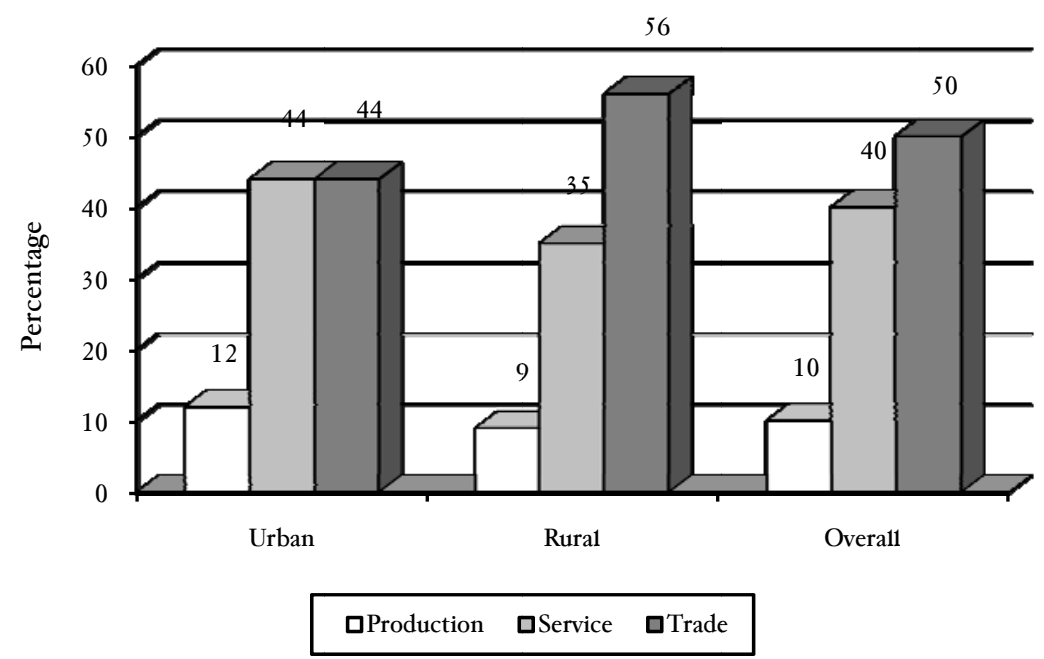

Source: Rural Pakistan Investment Climate Survey - World Bank 2005

Production enterprises account for only 10 percent of all enterprises, services for 40 percent and trade for the remaining 50 percent. The share of production in the total number of enterprises is quite small and is much less than the share of production reported from the review of international literature in the previous section. Rural enterprises are generally quite small in terms of asset size, employment levels and business turnover. The profile of the enterprises presented in the Tables 9 to 13 reveals that they are ill equipped to provide the catalytic growth enhancing, employment generating and poverty reducing role required from the RNFE or to cope with the risks associated with globalization.

Table-9: Profile of Rural Enterprises in Pakistan 2005

\begin{tabular}{lccc}
\hline & Rural & Small Town & Total \\
\hline Average No. of Workers & 1.97 & 2.05 & 2.01 \\
No. of Family Workers & 1.29 & 1.37 & 1.33 \\
No. of Hired Workers & 0.68 & 0.68 & 0.68 \\
Average Age (Years) & 9.17 & 9.03 & 9.10 \\
Stand-Alone Businesses (\%) & $94 \%$ & $67 \%$ & $80 \%$ \\
Share of Firms Registered (\%) & $28 \%$ & $20 \%$ & $24 \%$ \\
Sole Proprietorships (\%) & $95 \%$ & $94 \%$ & $94 \%$ \\
\hline
\end{tabular}


Table-10: Value of Rural Enterprise Assets

\begin{tabular}{lcc}
\hline & $\begin{array}{c}\text { Median Value of } \\
\text { Assets (-000 Rs) }\end{array}$ & $\begin{array}{c}\text { Average Value of } \\
\text { Assets (-000 Rs) }\end{array}$ \\
\hline Land & 25.0 & 146.5 \\
Building & 50.0 & 146.0 \\
Equipment \& Machinery & 5.0 & 23.0 \\
Furniture \& Storage Facilities & 1.5 & 5.5 \\
Tools & 1.0 & 3.3 \\
Vehicles & 1.8 & 17.0 \\
Other Fixed Assets & 1.0 & 15.4 \\
All & 16.5 & 92.0 \\
\hline
\end{tabular}

Table-11: Forward Linkages of Rural Non-Farm Enterprises

\begin{tabular}{lccc}
\hline & Production & Services & Trade \\
\hline Share of Sales To: & & & \\
Households & $55 \%$ & $82 \%$ & $89 \%$ \\
Traders & $12 \%$ & $0 \%$ & $0 \%$ \\
Multinationals & $0 \%$ & $1 \%$ & $0 \%$ \\
Parent Company or Affiliated & $1 \%$ & $1 \%$ & $0 \%$ \\
Subsidiaries & & & \\
Large Domestic Firms & $6 \%$ & $1 \%$ & $0 \%$ \\
Other (Small Firms, Farms Etc) & $27 \%$ & $16 \%$ & $11 \%$ \\
Share of Sales by Location: & & & \\
Same Tehsil & $74 \%$ & $98 \%$ & $100 \%$ \\
Different Tehsil in the Same District & $15 \%$ & $1 \%$ & $0 \%$ \\
Different District in the Same & $7 \%$ & $0 \%$ & $0 \%$ \\
Province & & & \\
Other Province & $2 \%$ & $0 \%$ & $0 \%$ \\
Other Country & $1 \%$ & $0 \%$ & $0 \%$ \\
\hline
\end{tabular}


Table-12: Backward Linkages of Rural Non-Farm Enterprises

\begin{tabular}{lccc}
\hline & Production & Services & Trade \\
\hline Value of Inputs Originating From: & & & \\
Households & $6 \%$ & $11 \%$ & $3 \%$ \\
Traders & $26 \%$ & & \\
Multinationals & $0 \%$ & $6 \%$ & $8 \%$ \\
Parent Company or Affiliated & $3 \%$ & $1 \%$ & $2 \%$ \\
Subsidiaries & & & \\
Large Domestic Firms & $14 \%$ & $12 \%$ & $11 \%$ \\
Other (Small Firms, Farms Etc) & $51 \%$ & $69 \%$ & $77 \%$ \\
Value of Inputs Originating From: & & & \\
Same Tehsil & $31 \%$ & $22 \%$ & $16 \%$ \\
Different Tehsil in the Same District & $22 \%$ & $16 \%$ & $20 \%$ \\
Different District in the Same Province & $31 \%$ & $49 \%$ & $47 \%$ \\
Other Province & $10 \%$ & $9 \%$ & $11 \%$ \\
Other Country & $6 \%$ & $4 \%$ & $5 \%$ \\
\hline
\end{tabular}

Table-13: Percent Using Some Form of Modern Practice/Service

\begin{tabular}{lccccc}
\hline Service & Retail & Wholesale & Storage & Transport & Total \\
\hline Engineering & 13.4 & 11.8 & 33.2 & 42.4 & 16.7 \\
Management & 3.9 & 7.2 & 21.4 & 8.1 & 7.0 \\
Marketing & 15.5 & 21.0 & 26.5 & 23.2 & 18.7 \\
Accounting & 6.7 & 8.2 & 25.5 & 6.1 & 9.1 \\
Legal & 5.4 & 9.6 & 21.9 & 25.3 & 9.5 \\
Insurance & 3.6 & 3.4 & 12.2 & 21.2 & 5.5 \\
Information Technology & 5.1 & 5.2 & 15.3 & 2.0 & 6.1 \\
\hline
\end{tabular}

While the relatively small number of production enterprises in Pakistan is a cause for concern, it also highlights the missed potential for value-addition. Of particular concern, however, is the relative absence of 
essential services so necessary for competing in the globalized environment. These is evident not only from the small number of enterprises reporting use of modern business services such as accounting and insurance, but also from the absence of the essential agricultural support services necessary to spur the low productivity agricultural activities required for agriculture to play its role as a driver of growth in the entire RNFE.

The surveys highlight several characteristics of the rural non-farm economy of Pakistan that are indicative of the constraints to its potential for growth and poverty reduction. These include:

1. Small Size of Enterprises - lack of collateral and high moral hazard

2. Predominantly Sole proprietorship - unregistered and stand alone

3. Primitive business practices and attitudes

4. Lack of standards and quality in all aspects of transactions

5. Limited Information Flow

6. Low human capital - Inability to Assess Market -Inability to grow

7. Limited Forward and Backward Linkages outside of Geographic Area

8. Lack of Access to Finance

9. Lack of Contracts and Enforcement

These characteristics signify the constraints to the development of domestic commerce. "Domestic commerce is the most pro-poor growth possibility in the country. Currently, it employs about 40 percent of the labor force and contributes about 52 percent to GDP. If it can be provided with an enabling environment, our estimates suggest that it could help increase the growth rate by at least 2 percentage points. In addition, a pick up of activity in this area would increase in construction activity, strong development in hotelling, retail shops, transport, warehousing, storage, and other service industries. The employment impact of this would be far larger than through investment in any other sector" [Nadeem U1 Haque 5 quoted in the Daily Nation August 2, 2006].

\footnotetext{
${ }^{5}$ Nadeem Ul Haque first conceived of the idea of domestic commerce in Pakistan and the work that ensued emanates largely from his intellectual leadership.
} 


\section{Rethinking Development Policy - The Road Ahead for Pakistan}

Proper development of the RNFE requires a vitalized and facilitating role for institutions ${ }^{6}$ that govern agriculture, the rural factor markets especially land, domestic commerce and international trade and the interlinkages between these. The rethinking of development strategy in Pakistan needs to be based on sound empirical research into the entire institutional environment. The role of government particularly needs to be re-examined and steps taken to ensure that such a role is facilitating and not constraining and distortionary. The government's role should be focused clearly on maximizing the growth and employment generation potential of the rural non-farm economy. Only then will sustained poverty reduction take place. Moreover, such a rethinking should ensure competitiveness in the global environment. This is not an easy task given the prevailing inefficiencies in the system and the low levels of development of the essential elements of the RNFE.

Most of the barriers relating to the underdevelopment of rural enterprise in Pakistan relate to the absence or inefficiency of institutions ${ }^{7}$. The institutional set up, which was the responsibility of the public sector, failed to deliver the goods and resulted in inefficient and mismatched systems. These in turn distorted the markets and constrained the development of the rural non-farm sector. The easy, smooth and equitable functioning of a market can be facilitated through supporting institutional mechanisms. For instance, legal and judicial institutions which eliminate the possibility of fraud or cheating and permit the enforcement of contracts coupled with a strong infrastructure will help to promote economic activity by reducing transaction costs. Similarly supportive legal, regulatory and

\footnotetext{
${ }^{6}$ The WDR (2002) terms institutions more generally as "the rules and organizations including informal norms that coordinate human behavior". Development experts are now increasingly taking a more institutional view of development policies. See for example the statement of the Nobel Laureate Douglass C. North that 'Neoclassical theory is simply an inappropriate tool to analyze and prescribe policies that will induce development' (p. 359) North, D. (1994), 'Economic Performance through Time', American Economic Review, 84. In Pakistan this view has been forcefully put forward in the work of Syed Akmal Hussain in recent years..

7 Institutional failures can be classified into administrative or market related. Administrative failures arise due to the inefficiency of the bodies that are responsible for providing the facilities or services, which they have been established for. Market failures occur when a market fails to operate efficiently or does not exist at all. Such failures create an unjust distribution of resources within the population. However, market regulation through an institutional framework can only be successful if the institutional setup itself is impartial and unbiased and if the laws and rules formed by these institutions are applicable to everyone.
} 
political institutions can further the development of RNFEs. Increasing competition in the world market requires institutions for quality control, capacity building, research and development, etc. as well as for information flow, reducing disputes, defining property rights and contracts, and increasing healthy competition in markets.

While highlighting the need of various institutional setups in promoting the non-farm economy it is necessary to bear in mind that one institution cannot function in isolation and needs to be complemented by other institutions. Institutions for the non-farm economy require well functioning institutions in the farm sector. Similarly, a well-established credit institution, for instance, shall fail to work without an expansive information network; and, an illiterate and unskilled population shall not be able to reap the benefit of the latest technology and innovations and increased information without the ability to comprehend these. Re-thinking development, therefore, requires re-thinking the entire institutional architecture. 


\section{References}

Government of Pakistan (GoP), 2006, Household Integrated Economic Survey 2004-05. Federal Bureau of Statistics, Islamabad.

Government of Pakistan, 2006, Labour Force Survey 2005-06. Federal Bureau of Statistics, Islamabad.

Government of Pakistan, 2006, Pakistan Economic Survey 2005-06. Islamabad: Finance Division, Economic Adviser's Wing.

Haggblade, Steven, Peter B. R. Hazell, and Thomas Reardon, 2007, Transforming the Rural Nonfarm Economy Opportunities and Threats in the Developing World. Johns Hopkins University Press: Baltimore.

Haque, Nadeem U1, 2006, The Daily Nation August 2, 2006

Innovative Development Strategies, 2005, Rural Investment Climate Survey 2005. Innovative Development Strategies, Islamabad and The World Bank, Washington D.C.

Innovative Development Strategies, 2006, Surveys of Domestic Commerce 2006. Innovative Development Strategies and Government of Pakistan.

World Bank, 2002, The World Development Report 2002. The World Bank, Washington D. C. 